\title{
Modification of an Existing In vitro Method to Predict Relative Bioavailable Arsenic in Soils
}

\section{Shane Whitacre ${ }^{\mathrm{a}}$, Nicholas Basta, ${ }^{\mathrm{a}^{*}}$ Brooke Stevens $^{\mathrm{b}}$, Valerie Hanley ${ }^{\mathrm{c}}$, Richard Anderson ${ }^{\mathrm{d}}$, Kirk Scheckel $^{\mathrm{e}}$ and Andrea Foster ${ }^{\mathrm{f}}$}

Abbreviations: GI, Gastrointestinal; IVBA, In Vitro Bioaccessible; OSU-IVG, Ohio State University In Vitro Gastrointestinal Method; CAB, California Arsenic Bioaccessibility Method; RBA, relative bioavailability; HHRA, human health risk assessment

Keywords: Arsenic; $\mathrm{CAB}$; human health risk assessment; contaminated soil; bioaccessibility, bioavailability,

\section{ABSTRACT}

The soil matrix can sequester arsenic (As) and reduces its exposure by soil ingestion. In vivo dosing studies and in vitro gastrointestinal (IVG) methods have been used to predict relative bioavailable (RBA) As. Originally, the Ohio State University (OSU-IVG) method predicted RBA As for soils exclusively from mining and smelting sites with a median of $5,636 \mathrm{mg} \mathrm{As} \mathrm{kg}^{-1}$. The objectives of the current study were to (i) evaluate the ability of the OSU-IVG method to predict RBA As for As contaminated soils with a wider range of As content and As contaminant sources, and (ii) evaluate a modified extraction procedure's ability to improve prediction of RBA As. In vitro bioaccessible (IVBA) by OSU-IVG and California Bioaccessibility Method (CAB) methods, RBA As, speciation, and properties of 33 As contaminated soils were determined. Total As ranged from 162 to $12,483 \mathrm{mg} \mathrm{kg}^{-1}$ with a median of $73 \mathrm{mg} \mathrm{kg}^{-1}$. RBA As ranged from 1.30 to $60.0 \%$ and OSU-IVG IVBA As ranged from 0.80 to $52.3 \%$. Arsenic speciation was predominantly $\mathrm{As}(\mathrm{V})$ adsorbed to hydrous ferric oxide $(\mathrm{HFO})$ or iron $(\mathrm{Fe})$, manganese $(\mathrm{Mn})$, and aluminum (Al) oxides. The OSU-IVG often extracted significantly less As in vitro than in vivo RBA As, in particularly for soils from historical gold mining. The CAB method, which is a modified OSU-IVG method extracted more As than OSU-IVG for most soils, resulting in a more accurate predictor than OSU-IVG, especially for low to moderately contaminated soils $\left(<1,500 \mathrm{mg} \mathrm{As} \mathrm{kg}^{-1}\right)$ with RBA As $=0.81$ IVBA As $+3.2, \mathrm{r}^{2}=0.91$. 


\section{Introduction}

Exposure risk associated with soils contaminated with arsenic (As) is assessed by human health risk assessment (HHRA). A critical component of HHRA is exposure assessment by various exposure pathways. In soils, often the most important pathway for As, the risk driver, associated with human exposure is incidental soil ingestion. However, use of total soil As often overestimates exposure because physiochemical properties of the soil matrix can sequester As and reduces its transmission through exposure pathways. Currently, the recommended default relative bioavailability (RBA) for soil As is 60\% (U.S. EPA, 2010).

A more accurate site-specific HHRA accounts for measured RBA of As in a soil matrix as part of the exposure assessment. Many sites have soils with As bioavailability less than the default thus resulting in an over-estimation of risk. Applying site-specific bioavailability allows for a more accurate risk assessment and may reduce the need or extent of remediation. Appropriate animal models, similar to human gastrointestinal (GI) physiology, are often used to determine bioavailability of As in contaminated soil. The most commonly used animal model for determining RBA As is the juvenile swine model (Rodriguez et al., 1999, Basta et al., 2007; Rees et al., 2009). In addition to juvenile swine, monkeys (Freeman et al., 1995; Roberts et al., 2002; Roberts et al., 2007), adult mouse (Bradham et al., 2011), and rabbit models (Freeman et al., 1993) have also been used. Use of animal models for determining RBA As has been reviewed by Basta and Juhasz (2014). Several disadvantages in conducting animal studies include expense, specialized facilities and personnel requirements, and time required to measure contaminant bioavailability.

In order to overcome some of the difficulties and expenses associated with animal dosing trials used to assess bioavailability of contaminants in soil, extensive research efforts have been directed toward development of in vitro methods that simulate the GI environment, to predict 
1 RBA As. While there are multiple efforts to advance development and adoption of an in vitro

2 bioaccessibility (IVBA) method, the two approaches in the United States employ pH buffered

3 and unbuffered extraction gastric fluids; a $0.4 \mathrm{M}$ glycine buffered gastric solution at pH 1.5

4 (Juhasz et al., 2006; Juhasz et al., 2007a, 2007b; Juhasz et al., 2008; Bradham et al., 2011;

5 Brattin et al., 2013; Diamond et al., 2016), and the OSU-IVG which consists of an unbuffered

6 gastric solution at $\mathrm{pH} 1.8$ followed by an unbuffered intestinal solution at pH 6.5 (Basta et al.,

7 2007; Nagar et al., 2009; Juhasz et al., 2009; Li et al., 2015). The experimental conditions of

8 many of the bioaccessibility methods are similar. The scope of the current study was to

9 investigate the effect of soil As content and source on the ability of bioaccessibility to predict

RBA As. However, it is beyond the scope of this study to investigate all bioaccessibility

11 methods and have selected the OSU IVG method for evaluation.

The OSU-IVG was the first in vitro method to be correlated with swine RBA As

13 (Rodriguez et al., 1999). Juvenile swine RBA As were determined using soil in a dosing vehicle

14 of wet feed. The OSU-IVG method of Rodriguez et al. (1999) incorporated this dosing vehicle

15 in the OSU-IVG method to determine bioaccessible As. Use of the dosing vehicle in the in vitro

16 method was problematic because (i) the IVG method should be developed for fasting conditions,

17 and (ii) obtaining the exact type of dosing vehicle is problematic making it difficult to

18 standardize the method for use by others. In Basta et al. (2007), bioaccessible As was

19 determined by OSU-IVG with and without the dosing vehicle. Basta et al. (2007) data for 10

20 soils was combined with IVBA As values for 4 soils (Basta et al., 2001) that did not use dosing

21 vehicle to obtain the following linear regression to predict RBA As.

22

$$
\% \text { RBA As }=0.883(\% \text { OSU-IVG GE })+9.6, \mathrm{r}^{2}=0.74
$$


1 The 14 soils used to produce Eqn. 1 were exclusively from mining and smelting sites with total

2 As contents ranging from 405 to $17,500 \mathrm{mg} \mathrm{As} \mathrm{kg}^{-1}$ with a median of $5,636 \mathrm{mg} \mathrm{As} \mathrm{kg}^{-1}$. In many

3 cases, these As concentrations are much higher than many soils for which bioavailability

4 adjustments would be considered and also much higher than the swine in vivo vs. in vitro

5 correlations (IVIVC) developed for the 0.4M glycine method reported by (Juhasz et al., 2009,

6 median of $262 \mathrm{mg} \mathrm{As} \mathrm{kg}^{-1}$ ) and Brattin et al. (2013, median of $385 \mathrm{mg} \mathrm{As} \mathrm{kg}^{-1}$ ). While it has been

7 demonstrated that IVBA As by the OSU-IVG is not related to total As content (Whitacre et al.,

8 2013), it is unknown how well the OSU-IVG method will measure and/or predict RBA over a

9 wider concentration range of soils As, particularly lower As concentrations, and from As sources

10 outside those used to develop the regression. The objectives of the current study were to (i)

11 evaluate the ability of the OSU-IVG method to predict RBA As for As contaminated soils with a

12 wider range of As content and As contaminant sources, and (ii) evaluate a modified extraction

13 procedure's ability to improve prediction of RBA As.

14 2. Materials and Methods

$15 \quad 2.1$ Study Soils

16 Thirty-three As containing soils that represent a wide variety of As sources were selected

17 for this study. Soil samples were homogenized and sieved to $<250 \mu \mathrm{m}$. Total content of As and

18 other elements were determined using microwave assisted acid digestion using a CEM

19 Corporation Mars Express Microwave (U.S. EPA Method 3051a, U.S. EPA, 2007a) with

20 subsequent analysis by inductively coupled plasma optical emission spectroscopy (ICP-OES)

21 using an Agilent 720 (U.S. EPA, 2007b). Reactive Fe was determined by the acid ammonium

22 oxalate method of McKeague and Day (1966). 
1 Other additional soil and solid waste analyses including soil $\mathrm{pH}$, organic carbon, electrical

2 conductivity, and soil texture have been reported previously (Basta et al., 2016). Arsenic

3 speciation was determined from As X-ray absorption near-edge structure (XANES) spectra and

4 the extended x-ray absorption fine structure (EXAFS). Linear combination, least-squares fitting

5 provided quantitative determination of species relative abundance in samples containing multiple

6 As or Fe species. Detailed procedures for arsenic speciation are described in Basta et al. (2016)

7 and California DTSC (2015).

$8 \quad 2.2$ Determination of Relative Bioavailable Arsenic

9 Juvenile swine bioassays were used to determine RBA As for the study soils according to

10 (Brattin and Casteel, 2013). In short, soils were administered to a dose group at a known As

11 levels for 15 days. Additionally, the study included a non-treated group to serve as a control for

12 determining background arsenic levels as well as a sodium arsenate reference group. All doses

13 were administered orally and As excreted in urine was used to determine RBA As for each soil.

14 Further details of the bioassay and RBA derivation are described in Basta (2016) and California

15 DTSC (2015).

$16 \quad 2.3$ Determination of Bioaccessible Arsenic

17 In vitro laboratory methods were used to determine IVBA As. The two IVBA methods

18 investigated were the OSU-IVG (Basta et al., 2007) and the California Arsenic Bioaccessibility

19 Method (CAB, California DTSC, 2015). Bioaccessible As was determined from the gastric

20 phase of both methods.

21

Bioaccessible As was determined by the OSU-IVG method as follows. The extraction

22 solution consisted of $0.10 \mathrm{M} \mathrm{NaCl}$ and $1 \%$ porcine pepsin. The solution was heated in an open

23 extraction vessel, in a $37^{\circ} \mathrm{C}$ hot water bath. When the solution reached $37^{\circ} \mathrm{C}$, soil $(1 \mathrm{~g},<250$ 
$1 \mu \mathrm{m})$ was added. The sample was thoroughly mixed with the solution using a paddle stirrer to

2 maintain a homogenous suspension, and the $\mathrm{pH}$ is adjusted drop wise to 1.8 using $6 \mathrm{M}$ trace metal

3 grade $\mathrm{HCl}$. The solution $\mathrm{pH}$ is continuously monitored and adjusted to $1.8 \pm 0.1$. After $1 \mathrm{~h}, 10$

$4 \mathrm{~mL}$ of gastric solution was removed for analysis. The extract was immediately centrifuged

$5 \quad(11,160 \mathrm{~g}$ for $15 \mathrm{~min})$ and then filtered $(0.45 \mu \mathrm{m})$. The extracted As is expressed as IVBA as

6 shown in eqn. 2.

$7 \quad$ IVBA As $(\%)=\left[\right.$ bioaccessible As $\left.\left(\mathrm{mg} \mathrm{kg}^{-1}\right)\right] /\left[3051 \mathrm{a} \mathrm{As}\left(\mathrm{mg} \mathrm{kg}^{-1}\right)\right] * 100$ [2]

8 Bioaccessible As was determined using the CAB method as follows. The extraction

9 solution consisted of $0.10 \mathrm{M} \mathrm{NaCl}, 1 \%$ porcine pepsin, and $100 \mathrm{mM}$ L-ascorbic acid at $\mathrm{pH}$ 1.5.

10 The extraction was conducted by the addition of $1.0 \mathrm{~g}$ soil $(<250 \mu \mathrm{m})$ to a $175 \mathrm{~mL}$ HDPE bottle

11 containing $150 \mathrm{~mL}$ of gastric solution (preheated to $37^{\circ} \mathrm{C}$ ) and placed into an end over end

12 rotator shaker located in a $37^{\circ} \mathrm{C}$ incubator. Soil samples were rotated at $40 \pm 2 \mathrm{rpm}$ for $2 \mathrm{~h}$.

13 Gastric solution $\mathrm{pH}$ was maintained at $1.5 \pm 0.1$ using drop wise $50 \% \mathrm{NaOH}$ (sodium hydroxide)

14 and/or $6 \mathrm{M}$ trace metal $\mathrm{HCl}$ solution. After $2 \mathrm{~h}, 10 \mathrm{~mL}$ aliquot of suspension was collected with a

15 syringe and filtered $(0.45 \mu \mathrm{m})$ for ICP-OES analysis. As extracted in the OSU-IVG and CAB

16 methods was determined by ICP-OES according to USEPA method 6010C using an Agilent 720

17 (USEPA 2007b).

182.4 Prediction of RBA As from IVBA As

The ability of the OSU-IVG method to predict RBA As for soils and solid wastes with

20 range in of soil As content as well as contaminant sources (objective 1) was evaluated as follows.

21 The predictive regressive (Eqn. 1) was used to calculate RBA As from IVBA As of the study

22 soils and regressed against the measure RBA As. In addition, analysis of Covariance

23 (ANCOVA) and simple linear regression (RBA As vs. IVBA As) were utilized evaluate the 
1 ability of the OSU-IVG and CAB methods to compare the predictive relationships of the two

2 methods.

\section{$3 \quad 3.0$ Results and Discussion}

$4 \quad 3.1$ Study Soils

Study soils had a wide range in As, reactive Fe content, and other key soil properties

6 required for a robust method evaluation (Table 1). Total As ranged from 162 to $12,483 \mathrm{mg} \mathrm{kg}^{-1}$

7 with a median of $731 \mathrm{mg} \mathrm{kg}^{-1}$, reactive Fe ranged from 0.56 to $120 \mathrm{~g} \mathrm{~kg}^{-1}$ with a median of $6.13 \mathrm{~g}$

$8 \mathrm{~kg}^{-1}$. There was also a wide range in both RBA and bioaccessible As; RBA As ranged from 1.30

9 to $60.0 \%$ and OSU-IVG IVBA As ranged from 0.80 to $52.3 \%$ (Table 1) due to a wide range in

10 key soil properties known to affect As solubility and bioaccessibility, including; organic C

11 content from 2.7 to $81.2 \mathrm{~g} \mathrm{~kg}^{-1}$, soil $\mathrm{pH}$ from 2.14 to 9.28 and clay content from 10 to $111 \mathrm{~g} \mathrm{~kg}^{-1}$

12 (California DTSC, 2015; Basta et al., 2016).

Specific soil properties that have been demonstrated to have an influence on As solubility

14 and bioaccessibility are iron oxides and $\mathrm{pH}$. Iron oxides adsorb As by ligand exchange with

15 hydroxyl groups at the oxide surface (Grossl and Sparks, 1995; Grossl et al., 1997). The amount

16 of As adsorbed to the oxide depends on the amount of oxide and therefore the number of

17 available coordination sites for arsenate. Maximum As adsorption densities of $0.25 \mathrm{~mol}$ of sites

18 per mol of Fe or on hydrous iron oxides have been reported (Dombak and Morel, 1990). Yang et

19 al. (2002) demonstrated a relationship between bioaccessible As in a physiologically based

20 extraction test (PBET) using a multiple regression equation with Fe measured by citrate

21 bicarbonate dithionite and soil $\mathrm{pH}$ as variables. Similarly, Whitacre et al. (2013) indicate that the

22 majority of non-bioaccessible As was associated with reactive Fe in soil. Solution $\mathrm{pH}$ affects

23 oxide surface charge and arsenate protonation, thereby affecting the adsorption of As. Arsenic 
$1 \operatorname{acid}\left(\mathrm{H}^{3} \mathrm{AsO}^{4}\right)$ dissociates with the following $\mathrm{pKa}$ values; $\mathrm{pKa} 1=2.2, \mathrm{pKa} 2=6.97$, and $\mathrm{pKa} 3=$

211.53 (Harris, 2003). As pH increases, the surface charge of iron oxide becomes more negative

3 as well as the charge on arsenate $\left(\mathrm{H}_{\mathrm{n}} \mathrm{AsO}_{3}{ }^{-\mathrm{n}}\right)$. The negative repulsion results in a decrease in As

4 absorption above $\mathrm{pH} 7$, which corresponds to an inflection point at $\mathrm{pKa} 2$ of the sorption

5 envelope for As (Goldberg, 2002; Raven et al., 1998).

6 In addition to soil properties, results of XANES and EXAFS arsenic speciation are also

7 presented in Table 1. Arsenic speciation was closely tied to Fe chemistry in the soils evidenced

8 by the most abundant As species being As(V) adsorbed to hydrous ferric oxide (HFO) or Fe, Mn,

9 and $\mathrm{Al}$ oxides (Table 1). However, lead $(\mathrm{Pb})$ arsenate was a significant As species in orchards

10 treated with lead arsenate pesticide. All study soils were aerobic topsoil, where oxidation of

$11 \mathrm{As}(\mathrm{III})$ to $\mathrm{As}(\mathrm{V})$ had mostly occurred, and the predominance of As adsorption to Fe mineral

12 surfaces is consistent with previous studies (Deschamps et al., 2003; Manning, 2005). The

13 geochemistry of As is commonly linked to Fe because of its strong specific bonding to arsenic as

14 well as the abundance of Fe in most soils (Bowell et al., 2014). Due to the affinity of As

15 oxyanions for surfaces of Fe oxides (Schwertmann and Taylor 1989; Carlson et al., 2002;

16 Kneebone et al., 2002) co-precipitation of As and Fe (sulfides) can also occur, resulting in strong

17 correlation coefficients between Fe and As (Smith et al., 2013). In mining-contaminated soil,

18 arsenopyrite is the most common mineral identified in association with sulfide minerals.

Chemical speciation using spectroscopic methods, including XANES and EXAFS, is

20 directly related to As bioaccessibility (Meunier et al., 2010, Table 2). Soils with As

21 predominantly as arsenopyrite or scorodite will likely have low bioaccessibility and

22 bioavailability. On the contrary, soils with As predominantly as $\mathrm{Ca}-\mathrm{Fe}$ arsenate minerals (i.e.,

23 yukonite) will likely have high bioaccessibility and bioavailability. While mixed mineral content 
1 in soil can make bioaccessibility and bioavailability difficult to predict, soil 30 in the current

2 study demonstrates the trend presented in Table 2 with As primarily present as arsenopyrite

3 (52\%), which corresponds to very low RBA As (4\%).

\subsection{Prediction of RBA As from IVBA As}

Predicted RBA from OSU-IVG IVBA As using Eqn. 1 is compared to the measured RBA for the current study soils (Fig. 1). The slope close to one indicates that on average, the OSUIVG could be predictive of the RBA. However, the low correlation coefficient $\left(\mathrm{r}^{2}=0.57\right)$ indicates that there can be large prediction error for individual soils, ranging from underprediction up 56\% (Soil 19) and over-prediction up to $879 \%$ (Soil 13). Under predictions generally occurs when the RBA As are high (>50\%) and the OSU-IVG IVBA As is considerably less as in than RBA As. In these cases, the y-intercept (9.6) of the regression is not enough to compensate for under-extraction of As, resulting in a predicted RBA As lower than the actual RBA As. On the other hand, over-prediction occurs when RBA As is low $(<10 \%)$ and the high y-intercept forces the predicted RBA As values above the measured. In both of these cases, the As source was different than the mining wastes used to develop Eqn. 1. Also, the soil As concentrations for these study soils were well below the median As of soils and solid wastes used to develop Eqn. 1. The limited ability of the OSU-IVG to predict RBA in soils outside of mining soils, especially low to moderate As concentrations, is in agreement with (Juhasz et al., 2009) in which the OSU-IVG was applied to railway (pesticide), cattle dip, mining, and gossans soils ranging from 42 to $1,118 \mathrm{mg} \mathrm{As} \mathrm{kg}-1$.

Further assessment of initial bioaccessibility testing indicated that the OSU-IVG extracted significantly less As in vitro than in vivo RBA As, in particularly for soils contaminated with waste rock and tailings from historical gold mining (Table 1, Fig. 2), on 
average extracting as little as $13 \%$ of RBA As (Soil 4). Soils in order of increasing As content

2 (Fig. 2), clearly show RBA As or IVBA As were not dependent on total As content. Linear

3 regression of RBA As vs. Total As produced an $\mathrm{r}^{2}=0.07$ which shows total As is not predictive

4 of RBA As. Previous studies have concluded that in vitro bioaccessible method extraction $\mathrm{pH}$ is

5 the parameter that most strongly influences IVBA As (Juhasz et al., 2009). However, we found

6 lowering the OSU-IVG pH from 1.8 to 1.5 alone did not increase IVBA As enough to make it an

7 accurate predictor of RBA As. A comprehensive review of the GI physiology literature revealed

8 a potentially key gastric constituent lacking from the OSU-IVG (Basta et al., 2007) is ascorbic

9 acid (AA). Ascorbic acid can lower the redox potential of gastric solution, thereby potential

10 increasing the solubility As, and is naturally secreted in the stomach (Maggi et al., 1957; Muto

11 et al., 1997; Muto et al., 1998; Tuo et al., 2000).

The addition of AA significantly impacted Eh, IVBA As, and dissolved Fe in the GI

13 extraction solution. Ascorbic acid decreased Eh (Fig. 3A) and increased IVBA As GE up to 100

14 mM AA (Fig. 3B), after which, increasing AA concentration had little additional effect (Fig.

15 3B). The dissolution of As with AA was significantly correlated $(P<0.01)$ with Fe dissolution

16 for the six soils (Fig.4).

The ability of the OSU-IVG and the AA modified method, the California Bioaccessibility

18 Method (CAB), to predict RBA As for all 33 study soils was determined by in vivo - in vitro

19 correlation (IVIVC) and presented in Figs. 5A and 5B respectively. Simple linear regression

20 (Fig. 5) produced almost identical results as weighted least squares analysis of covariance

21 (ANCOVA). The relationship between RBA As and OSU-IVG IVBA As was significant $\left(\mathrm{r}^{2}=\right.$

$220.57, P<0.01)($ Fig.. 5A), but weaker than the previous linear regression using soils exclusively

23 from mining and smelting with higher total As contents (405 to 17,500mg As kg ${ }^{-1}$ ) (Basta et al., 
1 2007, eq. 1). However, the modifications to the OSU-IVG to produce CAB, greatly improved

2 the relationship between RBA As and CAB IVBA As. The CAB method extracted significantly

3 more IVBA As than OSU-IVG for most soils, which more accurately mimics the RBA As from

4 the swine model. This resulted in an $\mathrm{r}^{2}=0.72(P<0.01)$ (Fig. 5B). In addition, the two methods

5 perform differently with increasing total soil As concentration. Analysis of 1:1 plot residuals

6 (IVBA As - RBA As) shows OSU-IVG IVBA $<$ RBA As at low total soil As concentrations but

7 IVBA As $\approx$ RBA As at higher soil As concentrations (Fig. 6A). The CAB method IVBA As $\approx$

8 RBA As at low total soil As concentrations but IVBA > RBA As at total soil As concentrations >

$9 \quad 1,500 \mathrm{mg} \mathrm{As} \mathrm{kg}^{-1}$ (Fig. 6B). The dependence on total As concentration on the 1:1 plot residuals could be due to in vitro extraction or to in vivo absorption processes. High concentrations of As

11 in soil can result in saturation of in vitro solution. Because IVBA As is a ratio of bioaccessible

12 As/total As, IVBA As would decrease with increasing total As if saturation occurred. In vivo GI

13 chemistry and/or physiology could also affect RBA As. Arsenic saturation of GI solution could

14 increase with total soil As limiting the mass of As available for absorption and the RBA As. The

15 increased positive plot residuals observed in our study is more likely due to in vivo GI chemistry

16 than in vitro chemistry. Plot residuals distributed around 0 (Fig. 6B) are consistent with less

17 likelihood of saturation of As in solution at lower Total As.

While the $\mathrm{CAB}$ method is less likely to underestimate RBA As for low to moderately

19 contaminated soils, it is more likely to overestimate RBA As for highly contaminated soils. The

20 plot residuals were positively biased for IVBA for $>1,500 \mathrm{mg} \mathrm{As} \mathrm{kg}^{-1}$. However, the plot

21 residuals were not biased for IVBA for $<1,500 \mathrm{mg} \mathrm{As} \mathrm{kg}^{-1}$. Based on the lack of bias observed

22 in Fig. 6B at $<1,500 \mathrm{mg} \mathrm{As} \mathrm{kg}^{-1}$, IVIVCs for the OSU-IVG and CAB for soils with $<1,500 \mathrm{mg}$

$23 \mathrm{As} \mathrm{kg}^{-1}$ were also compared (Fig.7). The OSU-IVG regression (Fig. 7A) showed little difference 
$1\left(\mathrm{r}^{2}=0.53\right)$ when total soil As concentration was restricted to $1,500 \mathrm{mg} \mathrm{As} \mathrm{kg}{ }^{-1}$. However, the

2 CAB method regression (Fig. 7B) further improved $\left(r^{2}=0.91, m=0.81\right)$. The improvement of

3 the $\mathrm{CAB}$ regression for soils with $<1,500 \mathrm{mg} \mathrm{As} \mathrm{kg}^{-1}$ is due primarily the increased As solubility

4 due to the AA that was added to the CAB method but absent in the OSU-IVG. AA lowered the

5 redox potential of gastric solution thereby potential increasing the solubility As. Ascorbic acid is

6 naturally secreted in the human stomach (Maggi et al., 1957; Muto et al., 1997; Muto et al.,

7 1998; Tuo et al., 2000) and likely in the swine stomach. Inclusion of AA in the gastric fluid

8 improved simulated in vivo conditions and likely improved the ability of IVBA to predict RBA 9 As.

The CAB IVIVC for soils $<1,500 \mathrm{mg} \mathrm{As} \mathrm{kg}^{-1}$ meets the suggested criteria for an

11 acceptable IVIVC, $\mathrm{r}^{2}>0.6$, and a slope between 0.8 and 1.2 (Wragg et al., 2011; Denys et al.,

12 2012). In addition, the $\mathrm{CAB}$ method meets the suggested criteria of a y-intercept that does not

13 deviate significantly from zero (Juhasz et al., 2014) with a y-intercept of 3.2. A large non-zero

$14 \mathrm{y}$-intercept in the in vitro in IVIVC is due to IVBA As results significantly less than RBA as

15 IVBA approaches zero in the data set used to generate the predictive equations and produces

16 prediction results. This was the case with the OSU-IVG in the current study $(y$-intercept $=11.2)$

17 as well as Juhasz et al. (2009) for which the OSU-IVG had a y-intercept of 14.3.

\section{4. Conclusions}

The OSU-IVG extracted significantly less As in vitro than in vivo RBA As, in

20 particularly for soils contaminated with waste rock and tailings from historical gold mining. The

21 CAB method, which is a modified OSU-IVG method that additionally contains ascorbic acid,

22 extracted more As than OSU-IVG for most soils. This resulted in a more accurate prediction of

23 RBA using the $\mathrm{CAB}$ method, particularly for low to moderately contaminated soils $(<1,500 \mathrm{mg}$ 
$\mathrm{As} \mathrm{kg}^{-1}$ ) with RBA As $=0.81$ IVBA As $+3.2, \mathrm{r}^{2}=0.91$. Accurate prediction at the low to

moderate soil arsenic contamination is pertinent to risk assessment because the low to moderate range is where bioavailability adjustments are most applicable. Further, the narrow confidence bands produced by the $\mathrm{CAB}$ method reduce the uncertainty associated with predicted RBA As. Extending the application of the CAB method above $1,500 \mathrm{mg} \mathrm{As} \mathrm{kg}^{-1}$ results in increased uncertainty in the prediction. However, CAB IVBA As can still be utilized as a conservative estimate of RBA As for soils above $1,500 \mathrm{mg} \mathrm{As} \mathrm{kg}^{-1}$.

\section{Acknowledgments}

The authors would like to acknowledge the funding for this research: SERDP Project ER-1742, Strategic Environmental Research and Development Program; and EPA Brownfields Training Research and Technical Assistance Grant "Arsenic Characterization/Bioavailability on MineScarred Lands. Additionally, we would like to acknowledge EPA California Department of Toxic Substance (DTSC) for their contribution to this effort and administering the Technical Assistance Grant, especially Perry Myers. Although EPA contributed to this article, the research presented was not performed by or funded by EPA and was not subject to EPA's quality system requirements. Consequently, the views, interpretations, and conclusions expressed in this article are solely those of the authors and do not necessarily reflect or represent EPA's views or policies.

\section{Literature Cited}

Basta, N.T., Rogriguez, R.R., R.R., Casteel S.W., 2001. Development of chemical methods to assess the bioavailability of arsenic in contaminated media. U.S. Environmental Protection Agency National Center for Environmental Research. EPA Grant Number R825410. Final Report.

Basta, N.T., Foster, J.N., Dayton, E.A., Rodriguez, R.R., Casteel, S.W., 2007. The effect of dosing vehicle on arsenic bioaccessibility in smelter-contaminated soils. J Environ Sci Heal A 42, 1275-1281.

Basta, N.T., Juhasz, A., 2014. Using In Vivo Bioavailability and/or In Vitro Gastrointestinal Bioaccessibility Testing to Adjust Human Exposure to Arsenic from Soil Ingestion. Reviews in Mineralogy and Geochemistry 79, 451-472.

Basta, N.T., Sevens, B.N., Whitacre, S.D., Scheckel, K.G., Betts, A., Bradham, K.D., Thomas, D.J., Schadt, C.W., 2016. Mechanisms and permanence of sequestered Pb and As in soils: impact 
on human bioavailability. SERDP Project ER-1742, Strategic Environmental Research and Development Program, Alexandria, VA. Final Report.

Bradham, K.D., Scheckel, K.G., Nelson, C.M., Seales, P.E., Lee, G.E., Hughes, M.F., Miller, B.W., Yeow, A., Gilmore, T., Serda, S.M., Harper, S., Thomas, D.J., 2011. Relative Bioavailability and Bioaccessibility and Speciation of Arsenic in Contaminated Soils. Environ Health Persp 119, 1629-1634.

Bowell, R. J., Alpers, C.N., Jamieson, H.E., Nordstrom, D.K., Majzlan, J., 2014. Arsenic: Environmental geochemistry, mineralogy, and microbiology. In: R.J. Bowell, J. Majzlan, and C. Alpers, editors, Geochemistry, Mineralogy and Microbiology of Arsenic in Environment. Mineral. Soc. Am., Chantilly, VA.

Brattin, W., Casteel, S., 2013. Measurement of arsenic relative bioavailability in swine. Journal of toxicology and environmental health. Part A 76, 449-457.

Brattin, W., Drexler, J., Lowney, Y., Griffin, S., Diamond, G., Woodbury, L., 2013. An In Vitro Method for Estimation of Arsenic Relative Bioavailability in Soil. J Toxicol Env Heal A 76, 458-478.

California Department of Toxic Substances Control Brownfields and Environmental Restoration Program.,2015. EPA Brownfields Training, Research and Technical Assistance Grant "Arsenic characterization/bioavailability on mine-scarred lands.” Final Technical Report.

Carlson, L., Bigham, J., Schwertmann, U., Kyek, A., Wagner, F., 2002. Scavenging of As from acid mine drainage by schwertmannite and ferrihydrite: a comparison with synthetic analogues. Environ Sci Technol, 36, 1712-1719.

Denys, S., Caboche, J., Tack, K., Rychen, G., Wragg, J., Cave, M., Jondreville, C., Feidt, C., 2012. In vivo validation of the unified BARGE method to assess the bioaccessibility of arsenic, antimony, cadmium, and lead in soils. Environ Sci Technol 46, 6252-6260.

Deschamps, E., Ciminelli, V.S., Weidler, P.G., Ramos A.Y., 2003. Arsenic sorption onto soils enriched in Mn and Fe minerals. Clays and Clay Minerals 51:197-204.

Diamond, G.L., Bradham, K.D., Brattin, W.J., Burgess, M., Griffin, S., Hawkins, C.A., Juhasz, A.L., Klotzbach, J.M., Nelson, C., Lowney, Y.W., Scheckel, K.G., Thomas, D.J., 2016.

Predicting oral relative bioavailability of arsenic in soil from in vitro bioaccessibility. J Toxicol Env Heal A 79, 165-173.

Dombak, D.A., Morel, F.M., 1990. Surface complexation modeling: Hydrous ferric oxide. John Wiley, New York. and mobility in the arsenic-rich historical mine waste dump. The Science of the total environment 536, 713-728. 
Freeman, G.B., Johnson, J.D., Killinger, J.M., Liao, S.C., Davis, A.O., Ruby, M.V., Chaney, R.L., Lovre, S.C., Bergstrom, P.D., 1993. Bioavailability of Arsenic in Soil Impacted by Smelter Activities Following Oral-Administration in Rabbits. Fund Appl Toxicol 21, 83-88.

Freeman, G.B., Schoof, R.A., Ruby, M.V., Davis, A.O., Dill, J.A., Liao, S.C., Lapin, C.A., Bergstrom, P.D., 1995. Bioavailability of arsenic in soil and house dust impacted by smelter activities following oral administration in cynomolgus monkeys. Fund Appl Toxicol 28, 215222.

Goldberg, S., 2002. Competitive adsorption of arsenate and arsenite on oxide and clay minerals. Soil Sci. Soc. Am. J. 66,413-421.

Grossl, P.R., Sparks, D.L., 1995. Evaluation for contaminant ion adsorption-desorption on goethite using pressure-jump relaxation kinetics. Geoderma. 67,87-101.

Grossl, P.R., Sparks, D.L., Goldberg, S., Ainsworth, C.C., 1997. Arsenate and chromate retention mechanism on goethite. 2. Kinetic evaluation using a pressure-jump technique. Environ. Sci. Technol. 31,321-326.

Harris, D.C. 2003., Quantitative chemical analysis. Sixth edition. W. H. Freeman and Company, New York.

Juhasz, A.L., Smith, E., Nelson, C., Thomas, D.J., Bradham, K., 2014. Variability associated with as in vivo-in vitro correlations when using different bioaccessibility methodologies. Environ Sci Technol 48, 11646-11653.

Juhasz, A.L., Smith, E., Weber, J., Naidu, R., Rees, M., Rofe, A., Kuchel, T., Sansom, L., 2008. Effect of soil ageing on in vivo arsenic bioavailability in two dissimilar soils. Chemosphere 71, 2180-2186.

Juhasz, A.L., Smith, E., Weber, J., Rees, M., Rofe, A., Kuchel, T., Sansom, L., Naidu, R., 2006. In vivo assessment of arsenic bioavailability in rice and its significance for human health risk assessment. Environ Health Persp 114, 1826-1831.

Juhasz, A.L., Smith, E., Weber, J., Rees, M., Rofe, A., Kuchel, T., Sansom, L., Naidu, R., 2007a. Comparison of in vivo and in vitro methodologies for the assessment of arsenic bioavailability in contaminated soils. Chemosphere 69, 961-966.

Juhasz, A.L., Smith, E., Weber, J., Rees, M., Rofe, A., Kuchel, T., Sansom, L., Naidu, R., 2007b. In vitro assessment of arsenic bioaccessibility in contaminated (anthropogenic and geogenic) soils. Chemosphere 69, 69-78.

Juhasz, A.L., Weber, J., Smith, E., Naidu, R., Rees, M., Rofe, A., Kuchel, T., Sansom, L., 2009. Assessment of four commonly employed in vitro arsenic bioaccessibility assays for predicting in vivo relative arsenic bioavailability in contaminated soils. Environ Sci Technol 43, 9487-9494. 
Kneebone, P.E., O'Day, P.A., Jones, N., Hering, J.G., 2002. Deposition and fate of arsenic in iron- and arsenic-enriched reservoir sediments. Environ Sci Technol 36, 381-386.

Li, J., Li, K., Cui, X.Y., Basta, N.T., Li, L.P., Li, H.B., Ma, L.Q., 2015. In vitro bioaccessibility and in vivo relative bioavailability in 12 contaminated soils: Method comparison and method development. The Science of the total environment 532, 812-820.

Maggi, A.L., Meeroff, M., Iovine, E., 1957. [Ascorbic acid in stomach secretion]. Prensa medica argentina 44, 1373-1380.

Manning, B., 2005. Arsenic speciation in As(III)- and As(V)-treated soil using XANES spectroscopy. Microchim Acta 151, 181-188.

McKeague, J.A., Day, J.H., 1966. Dithionite- and oxalate-extractable Fe and Al as aids in differentiating various classes of soils. Can. J. Soil Sci. 46,13-23.

Meunier, L., Walker, S.R., Wragg, J., Parsons, M.B., Koch, I., Jamieson, H.E., Reimer, K.J., 2010. Effects of Soil Composition and Mineralogy on the Bioaccessibility of Arsenic from Tailings and Soil in Gold Mine Districts of Nova Scotia. Environ Sci Technol 44, 2667-2674.

Muto, N., Eguchi, R., Akagi, Y., Itoh, N., Tanaka, K., 1998. Cholecystokinin stimulates ascorbic acid secretion through its specific receptor in the perfused stomach of rats. Research communications in molecular pathology and pharmacology 101, 127-136.

Muto, N., Ohta, T., Suzuki, T., Itoh, N., Tanaka, K., 1997. Evidence for the involvement of a muscarinic receptor in ascorbic acid secretion in the rat stomach. Biochemical pharmacology 53, 553-559.

Nagar, R., Sarkar, D., Makris, K.C., Datta, R., Sylvia, V.L., 2009. Bioavailability and Bioaccessibility of Arsenic in a Soil Amended with Drinking-Water Treatment Residuals. Arch Environ Con Tox 57, 755-766.

Raven, K.P., Jain, A., Loeppart, R.H. 1998., Arsenite and arsenate adsorption on ferrihydrite: Kinetics, Equilibrium, and adsorption envelopes. Environ Sci Technol 32,344-349.

Rees, M., Sansom, L., Rofe, A., Juhasz, A.L., Smith, E., Weber, J., Naidu, R., Kuchel, T., 2009. Principles and application of an in vivo swine assay for the determination of arsenic bioavailability in contaminated matrices. Environ Geochem Hlth 31, 167-177.

Roberts, S.M., Munson, J.W., Lowney, Y.W., Ruby, M.V., 2007. Relative oral bioavailability of arsenic from contaminated soils measured in the cynomolgus monkey. Toxicol Sci 95, 281-288.

Roberts, S.M., Weimar, W.R., Vinson, J.R.T., Munson, J.W., Bergeron, R.J., 2002. Measurement of arsenic bioavailability in soil using a primate model. Toxicol Sci 67, 303-310. Rodriguez, R.R., Basta, N.T., 1999. An in vitro gastrointestinal method to estimate bioavailable arsenic in contaminated soils and solid media. Environ Sci Technol 33, 642-649. 
1 Schwertmann, U., Taylor, R., 1989. Iron Oxides. Minerals in Soil

2 Environments(mineralsinsoile), 379-438.

3 Smith, D.B., Cannon, W.F., Woodruff, L.G., Solano, Federico, Kilburn, J.E., Fey, D.L., 2013,

4 Geochemical and mineralogical data for soils of the conterminous United States: U.S. Geological

5 Survey Data Series 801, 19 p.,http://pubs.usgs.gov/ds/801/.

6 Tuo, B.G., Yan, Y.H., Ge, Z.L., Ou, G.W., Zhao, K., 2000. Ascorbic acid secretion in the human 7 stomach and the effect of gastrin. World J Gastroenterol 6, 704-708.

USEPA, 2007a. Method 3051a. Mircowave Assisted Acid Digestion of Sediments, Sludges, 10 Soils, and Oils. SW-846. USEPA, Washington, DC.

USEPA, 2007b. Method 6010C. Inductively coupled plasma-atomic emission spectrometry. In SW-846. U.S. Environmental Protection Agency, Washington, DC.

14 USEPA, 2010. Region 8 Recommendations for Quantifying the Bioavailability of Lead and 15 Arsenic in Soil for Use in Human Health Risk Assessment.

16 http://www.epa.gov/region8/r8risk/hh_rba.html

17 Whitacre, S.D., Basta, N.T., Dayton, E.A., 2013. Bioaccessible and non-bioaccessible fractions 18 of soil arsenic. J Environ Sci Heal A 48, 620-628.

Wragg, J., Cave, M., Basta, N., Brandon, E., Casteel, S., Denys, S., Gron, C., Oomen, A.,

21 Reimer, K., Tack, K., Van de Wiele, T., 2011. An inter-laboratory trial of the unified BARGE

22 bioaccessibility method for arsenic, cadmium and lead in soil. The Science of the total

23 environment 409, 4016-4030. 
Figures

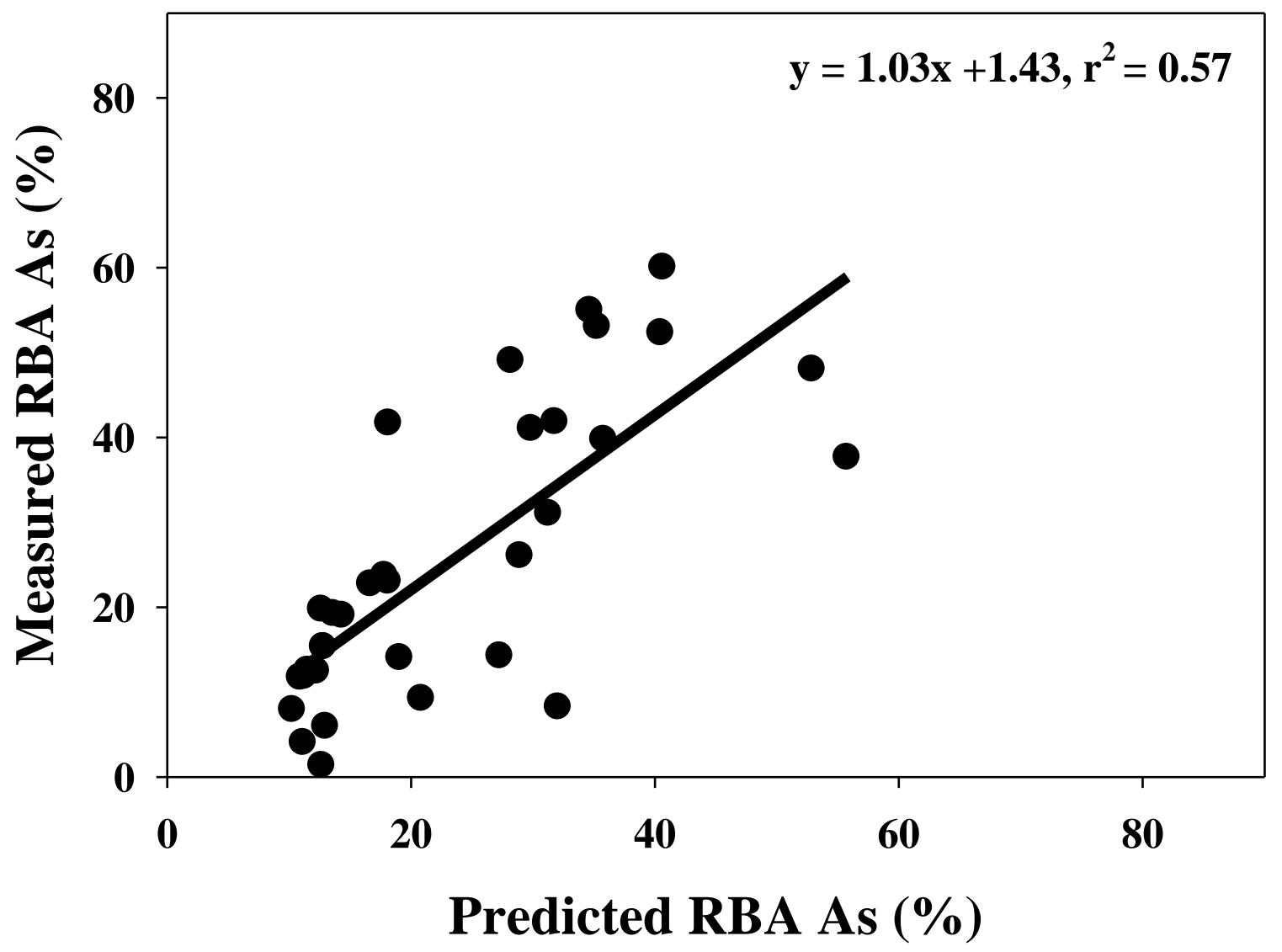

Figure 1. Measured RBA As in current study soils vs. predicted RBA As using the OSU-IVG and eqn. 1. 


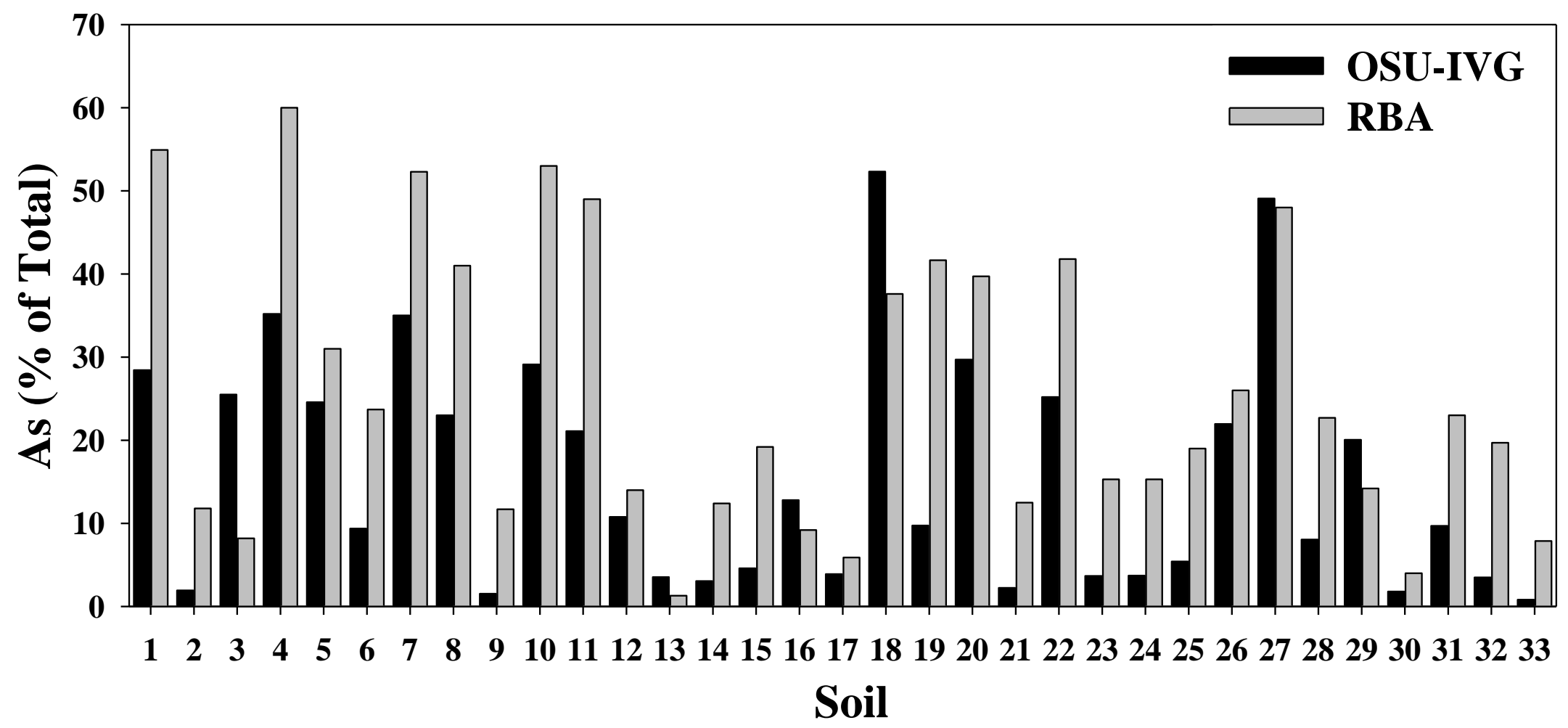

Figure 2. Comparison of bioacessible arsenic extracted by OSU-IVG with relative bioavailable (RBA) As in order of increasing total soil As concentration. 


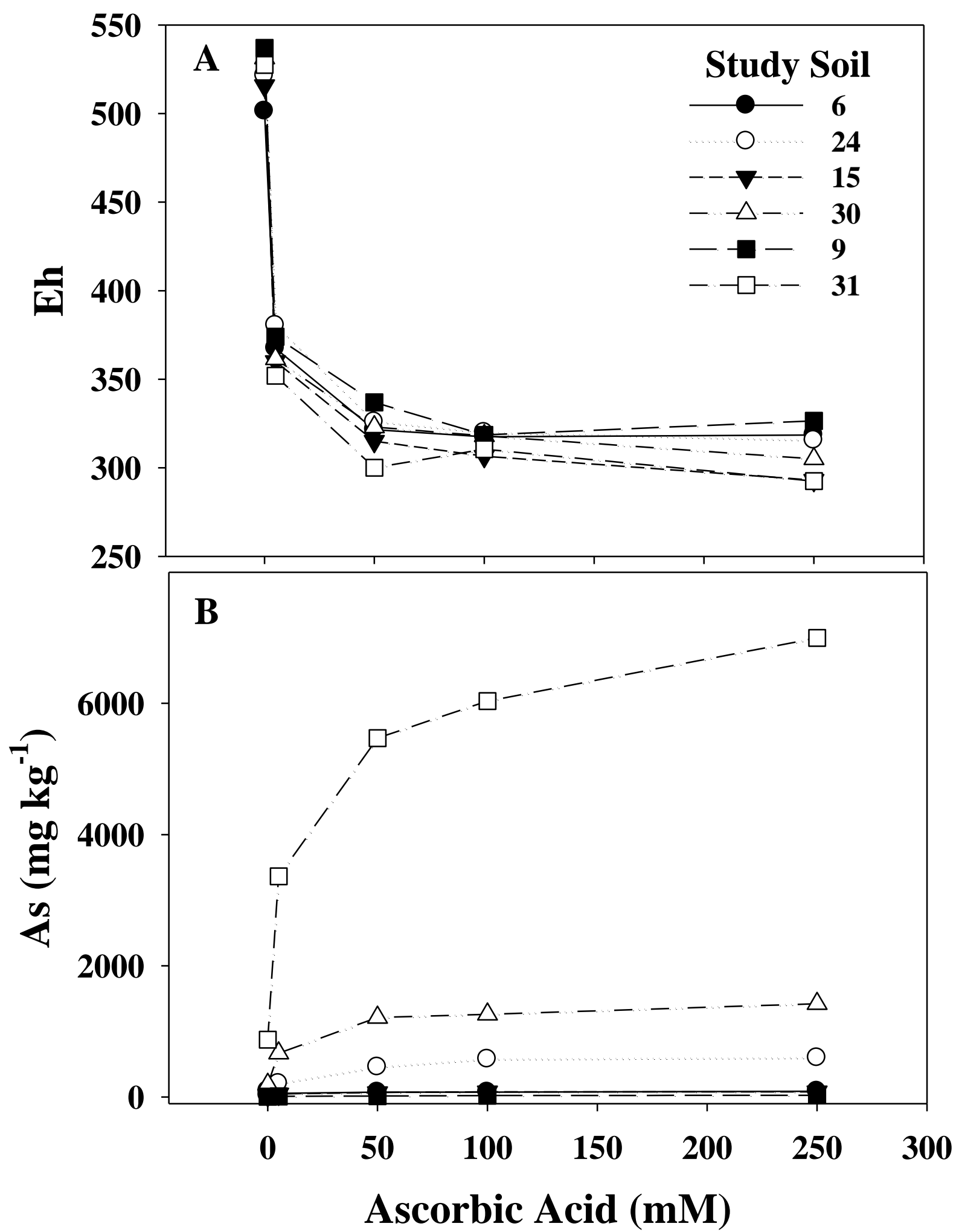

Figure 3. Effect of ascorbic acid addition to gastric solution on redox potential (A) and arsenic dissolution (B) for six study soils. 


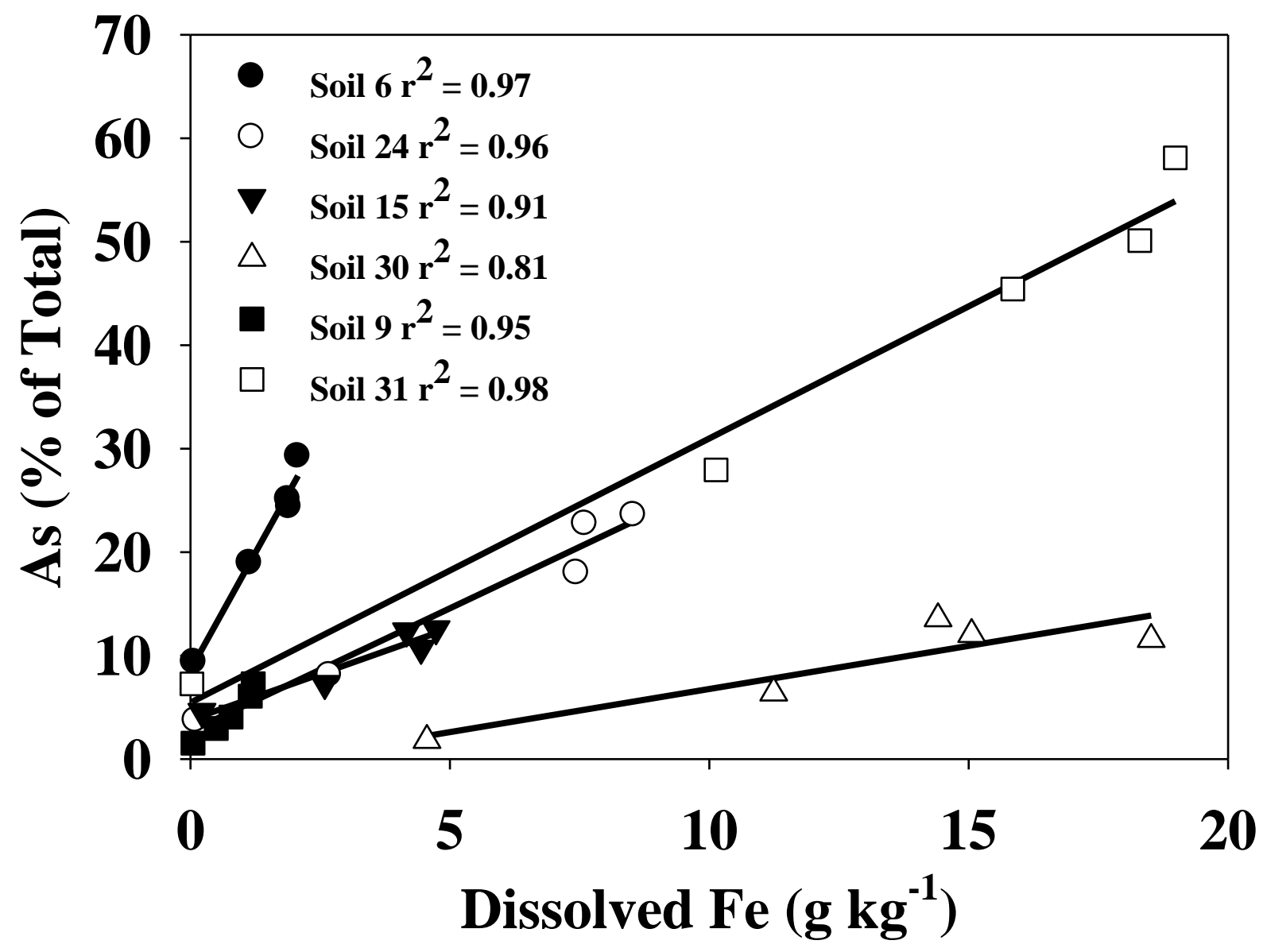

Figure 4. The relationship between arsenic dissolution and dissolved iron in gastric solution with increasing ascorbic acid additions $(0,50,100$, and $250 \mathrm{mM})$ for six study soils. 


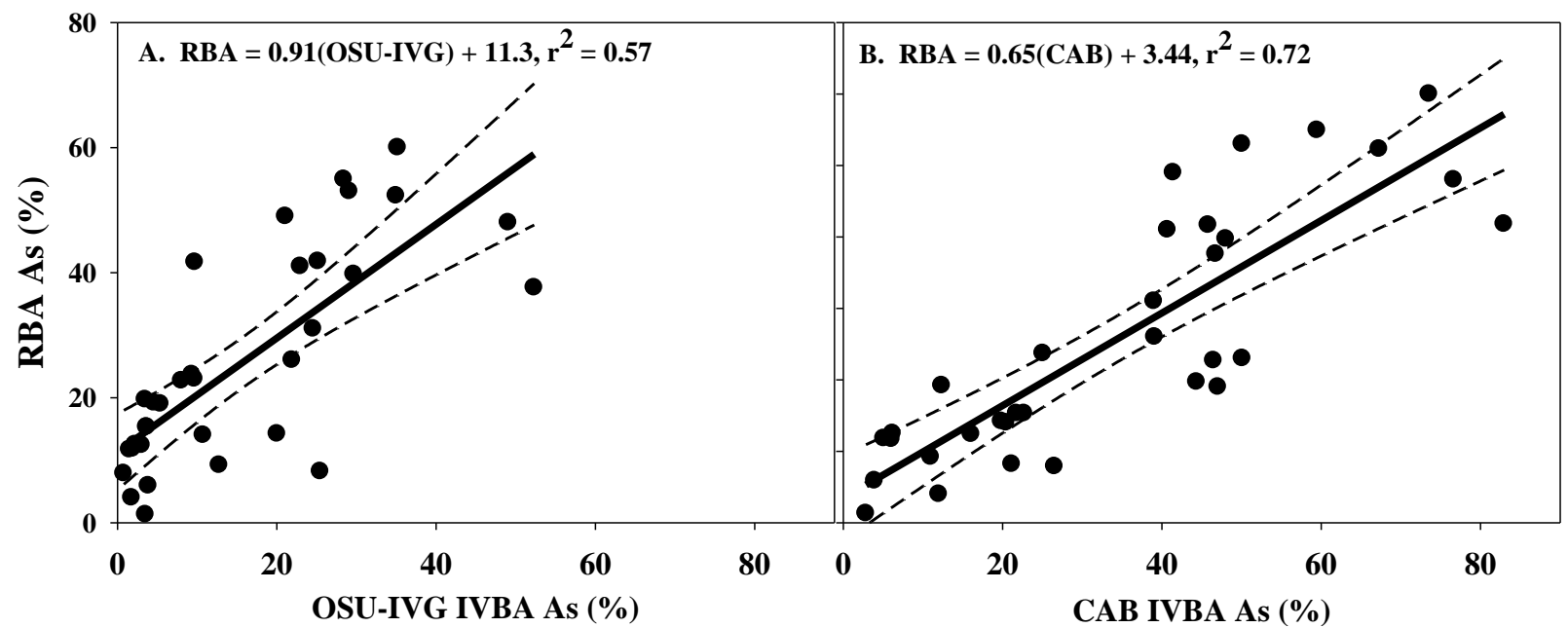

Figure 5. Comparison of regressions; RBA As vs. IVBA As form the OSU-IVG (A) and CAB (B) methods. Dashed lines represent 


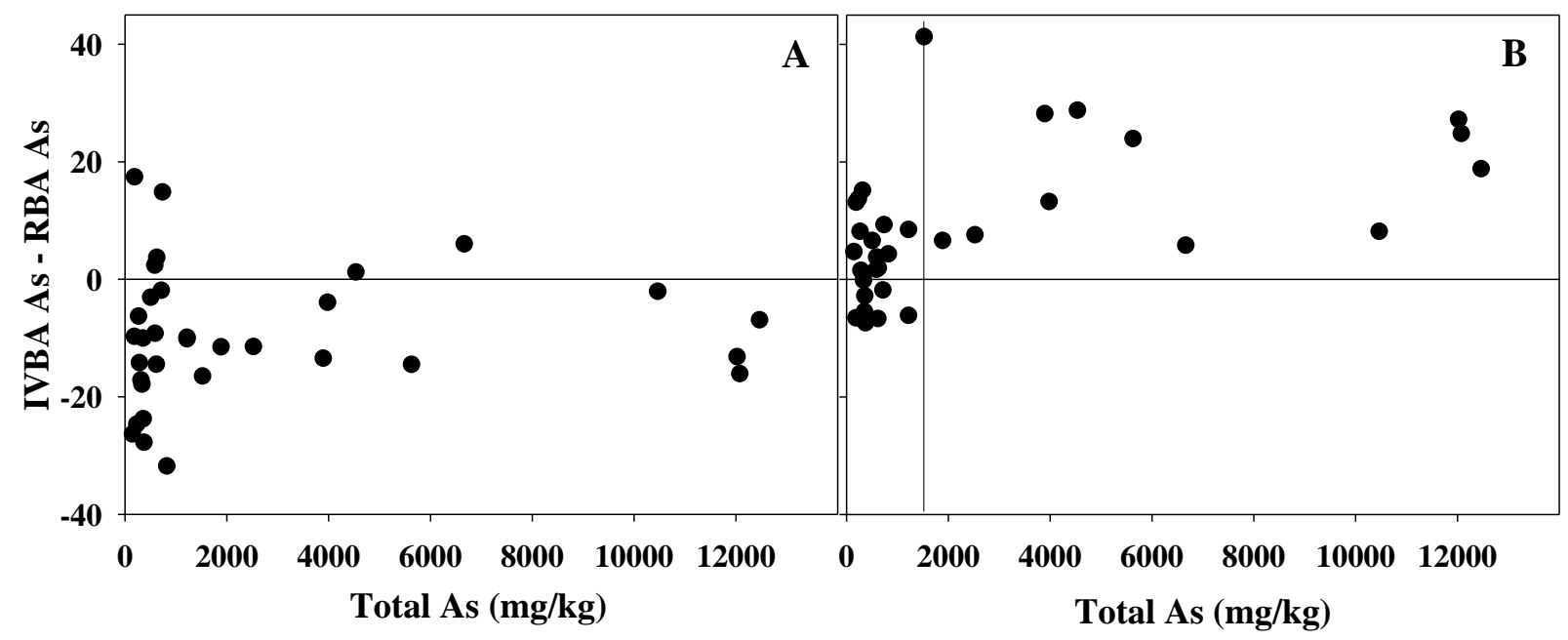

Figure 6. Comparison of relative bioavailable (RBA) As and in vitro bioaccessible (IVBA) As with total soil As concentration using 1:1 plot residuals (IVBA As - RBA As) for the OSU-IVG (A) and $\mathrm{CAB}(\mathrm{B})$ methods. Vertical line in plot $\mathrm{B}$ is placed at $1,500 \mathrm{mg} \mathrm{As} / \mathrm{kg}$. 


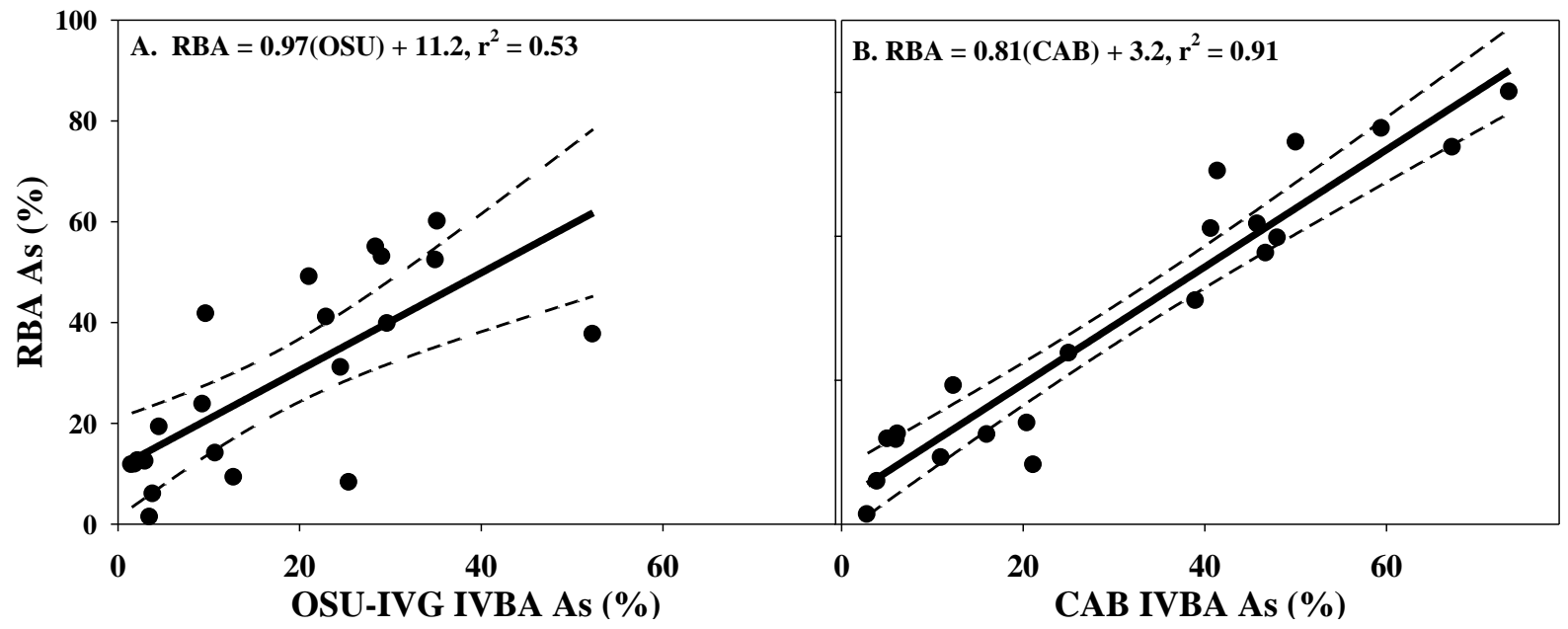

Figure 7. Comparison of regressions; RBA As vs. IVBA As form the OSU-IVG (A) and CAB (B) methods for soils with less than 1,500 mg As/kg. 


\section{Tables}

Table 1

Characterization of study soils by source, primary and secondary arsenic phases, total arsenic, reactive iron, relative bioavailable arsenic and in vitro bioaccessible As by OSU-IVG and CAB methods.

\begin{tabular}{|c|c|c|c|c|c|c|c|c|}
\hline Soil & Source & $\begin{array}{c}\text { Primary } \\
\text { As Phase* } \\
(\%)\end{array}$ & $\begin{array}{c}\text { Secondary } \\
\text { As Phase } \\
(\%)\end{array}$ & $\begin{array}{l}\text { Total As } \\
\left(\mathrm{mg} \mathrm{kg}^{-1}\right)\end{array}$ & $\begin{array}{l}\text { Reactive Fe } \\
\qquad\left(\mathrm{g} \mathrm{kg}^{-1}\right)\end{array}$ & $\begin{array}{l}\mathrm{RBA} \\
(\%)\end{array}$ & $\begin{array}{l}\text { OSU-IVG } \\
(\%)\end{array}$ & $\begin{array}{l}\text { CAB } \\
(\%)\end{array}$ \\
\hline 1 & $\begin{array}{c}\text { Copper Smelting } \\
\text { Residential Area Near Gold }\end{array}$ & $\mathrm{G}(47)$ & B (32) & 162 & 4.99 & 54.9 & 28.4 & 59.5 \\
\hline 2 & Mining & A (74) & $\mathrm{D}(14)$ & 203 & 2.11 & 11.8 & 1.92 & 5.10 \\
\hline 3 & $\begin{array}{c}\text { Silver Mining } \\
\text { Residential Area Near Iron }\end{array}$ & ${ }^{\mathrm{b}} \mathrm{NA}$ & ${ }^{\mathrm{b}} \mathrm{NA}$ & 205 & 0.560 & 8.2 & 25.5 & 21.2 \\
\hline 4 & Mining & $\mathrm{C}(51)$ & A (38) & 249 & 34.8 & 60.0 & 35.2 & 73.6 \\
\hline 5 & Lead Arsenate Pesticide & B (66) & $\mathrm{E}(25)$ & 283 & 2.37 & 31.0 & 24.6 & 39.0 \\
\hline 6 & Gold Mining & $\mathrm{A}(72)$ & $\mathrm{D}(10)$ & 302 & 6.30 & 23.7 & 9.36 & 25.1 \\
\hline 7 & Lead Arsenate Pesticide & $\mathrm{B}(71)$ & E (16) & 332 & 4.59 & 52.3 & 35.0 & 67.3 \\
\hline 8 & Lead Arsenate Pesticide & $\mathrm{B}(71)$ & $\mathrm{E}(23)$ & 353 & 5.73 & 41.0 & 23.0 & 40.7 \\
\hline 9 & Gold Mining & A (73) & $\mathrm{B}(20)$ & 370 & 2.33 & 11.7 & 1.52 & 6.07 \\
\hline 10 & Lead Arsenate Pesticide & $\mathrm{B}(71)$ & $\mathrm{E}(23)$ & 375 & 7.23 & 53.0 & 29.1 & 50.1 \\
\hline 11 & Lead Arsenate Pesticide & B (86) & $\mathrm{E}(15)$ & 391 & 5.97 & 49.0 & 21.1 & 41.4 \\
\hline 12 & Tailings from Mine Site & $C(56)$ & A (44) & 521 & 0.770 & 14.0 & 10.8 & 20.5 \\
\hline 13 & $\begin{array}{c}\text { Gold Mining } \\
\text { Residential Area Near Gold }\end{array}$ & NA & NA & 603 & 1.43 & 1.30 & 3.54 & 2.86 \\
\hline 14 & Mining & $A(65)$ & $\mathrm{D}(19)$ & 610 & 4.36 & 12.4 & 3.0 & 16.1 \\
\hline 15 & Gold Mining & A (53) & B (24) & 633 & 18.5 & 19.2 & 4.6 & 12.4 \\
\hline 16 & Gold Mining & ${ }^{\mathrm{b}} \mathrm{NA}$ & ${ }^{\mathrm{b}} \mathrm{NA}$ & 641 & 4.39 & 9.2 & 12.8 & 11.0 \\
\hline 17 & Iron, silver, gold Mining & ${ }^{\mathrm{b}} \mathrm{NA}$ & ${ }^{\mathrm{b}} \mathrm{NA}$ & 731 & 10.8 & 5.90 & 3.88 & 3.95 \\
\hline 18 & Gold Mining & ${ }^{\mathrm{b}} \mathrm{NA}$ & ${ }^{\mathrm{b}} \mathrm{NA}$ & 753 & 14.5 & 37.6 & 52.3 & 46.8 \\
\hline 19 & Gold Mining & B (74) & A (14) & 839 & 5.01 & 41.7 & 9.7 & 45.8 \\
\hline 20 & Slag from Copper Mining & $\mathrm{C}(78)$ & $\mathrm{B}(13)$ & 1,236 & 54.5 & 39.7 & 29.7 & 48.0 \\
\hline
\end{tabular}




\section{Table 1 Continued}

Characterization of study soils by source, primary and secondary arsenic phases, total arsenic, reactive iron, relative bioavailable arsenic and in vitro bioaccessible As by OSU-IVG and CAB methods.

\begin{tabular}{|c|c|c|c|c|c|c|c|c|}
\hline Soil & Source & $\begin{array}{c}\text { Primary } \\
\text { As Phase } \\
(\%)\end{array}$ & $\begin{array}{c}\text { Secondary } \\
\text { As Phase } \\
(\%)\end{array}$ & $\begin{array}{l}\text { Total As } \\
\left(\mathrm{mg} \mathrm{kg}^{-1}\right)\end{array}$ & $\begin{array}{l}\text { Reactive Fe } \\
\qquad\left(\mathrm{g} \mathrm{kg}^{-1}\right)\end{array}$ & $\begin{array}{c}\text { RBA } \\
(\%)\end{array}$ & $\begin{array}{l}\text { OSU-IVG } \\
(\%)\end{array}$ & $\begin{array}{l}\mathrm{CAB} \\
(\%)\end{array}$ \\
\hline 21 & Gold Mining & A (84) & H (8) & 1,237 & 1.15 & 12.5 & 2.22 & 6.22 \\
\hline 22 & SRM 2710A & $\mathrm{C}(82)$ & A (10) & 1,540 & 12.7 & 41.8 & 25.2 & 83.0 \\
\hline 23 & Gold Mining & A (70) & $\mathrm{D}(20)$ & 1,906 & 17.3 & 15.30 & 3.66 & 21.8 \\
\hline 24 & Gold Mining & A (70) & B (19) & 2,541 & 23.1 & 15.30 & 3.70 & 22.7 \\
\hline 25 & $\begin{array}{l}\text { Tailing from Mine or Smelter } \\
\text { Residential Area Near Glass }\end{array}$ & $\mathrm{C}(57)$ & A (33) & 3,913 & 36.2 & 19.0 & 5.4 & 47.1 \\
\hline 26 & Manufacturing & $A(100)$ & & 3,996 & 3.70 & 26.0 & 21.9 & 39.1 \\
\hline 27 & Glass Manufacturing & A (100) & & 4,553 & 4.97 & 48.0 & 49.1 & 76.7 \\
\hline 28 & Gold Mining & A (66) & B (29) & 5,647 & 25.1 & 22.7 & 8.05 & 46.51 \\
\hline 29 & Gold Mining & ${ }^{\mathrm{b}} \mathrm{NA}$ & ${ }^{\mathrm{b}} \mathrm{NA}$ & 6,681 & 8.99 & 14.2 & 20.1 & 19.9 \\
\hline 30 & Gold Mining & $\mathrm{F}(52)$ & $\mathrm{A}(21)$ & 10,482 & 26.0 & 4.0 & 1.8 & 12.0 \\
\hline 31 & Gold Mining & A (69) & $\mathrm{D}(8)$ & 12,041 & 32.5 & 23.0 & 9.68 & 50.10 \\
\hline 32 & $\begin{array}{c}\text { Gold Mining } \\
\text { Calcine Material from Copper }\end{array}$ & A (66) & B (17) & 12,095 & 36.3 & 19.7 & 3.50 & 44.38 \\
\hline \multirow[t]{5}{*}{33} & Mining & $\mathrm{B}(67)$ & A (33) & 12,483 & 120 & 7.9 & 0.8 & 26.5 \\
\hline & & & Min & 162 & 0.560 & 1.300 & 0.802 & 2.861 \\
\hline & & & Mean & 2,694 & 16.3 & 25.7 & 15.8 & 34.3 \\
\hline & & & Median & 731 & 6.302 & 19.700 & 9.722 & 39.023 \\
\hline & & & Max & 12,483 & 119.540 & 60.000 & 52.315 & 82.969 \\
\hline $\begin{array}{l}{ }^{\mathrm{a}} \mathrm{As}(\mathrm{V}) \\
{ }^{\mathrm{a}} \mathrm{As}(\mathrm{V}) \\
{ }^{\mathrm{a}} \mathrm{Hydrol} \\
{ }^{\mathrm{a}} \text { Arsena } \\
{ }^{\mathrm{a}} \text { Lead A }\end{array}$ & $\begin{array}{l}\text { Hydrous Ferric Oxide - A } \\
\text { Al/Fe/Mn Oxides - B } \\
\text { Ferric Arsenate - C } \\
\text { Jarosite - D } \\
\text { nate - E }\end{array}$ & \multicolumn{7}{|c|}{$\begin{array}{l}{ }^{\mathrm{a}} \text { Arsenopyrite - F } \\
{ }^{\mathrm{a}} \mathrm{As}(\mathrm{III}) \text { ads Fe/Al Oxides or Al } \\
{ }^{\mathrm{a}} \mathrm{Ca} \text { and } \mathrm{Ca}-\mathrm{Fe} \text { Arsenates - H } \\
{ }^{\mathrm{b}} \text { Data not available }\end{array}$} \\
\hline
\end{tabular}




\section{Table 2}

Arsenic mineralogy and bioaccessibility ranking (Adapted from Meunier et al. 2010) from most bioaccessible (1) to least bioaccessible (8).

\begin{tabular}{ccc} 
General Phase & Specific Phase & $\begin{array}{c}\text { Bioaccessibility } \\
\text { Ranking }\end{array}$ \\
\hline Calcium-Iron Arsenates & Yukonite, Asiderite, Calcium Arsenate & 1 \\
Clay Minerals & Undifferentieated & 2 \\
Sulfates & Tooeleite, Jarosite, Schwertmannite & 3 \\
As bearing Aluminum \\
$\begin{array}{c}\text { (oxy) Hydroxides } \\
\text { Roaster Iron Oxides }\end{array}$ & Gibbsite, AlOH3, As(III) sorbed to Kaolin & 4 \\
Arsenic bearing & Hematite, Maghemite & 5 \\
Iron(oxy) Hydroxides & Goethite, Lepidocrocite, Akaganeite, & \\
& Ferrihydrite & 6 \\
Iron Arsenates & Scorodite, Kankite, Pharmacosiderate, & \\
& Amorphous & 7 \\
Sulfides & Arsenopyrite, Realgar, Pyrite, Orpiment & 8 \\
\hline
\end{tabular}

